\title{
MULTIPLE RETAINED TEETH IN MANDIBLE: A CASE REPORT
}

\author{
Cvetanov C., Chenchev I., Bakardjiev A. \\ Departament of Oral Surgery, Faculty of Dental Medicine, \\ Medical University - Plovdiv, Bulgaria
}

\begin{abstract}
:
Purpose: The aim of this science report is to show a rare case of multiple impacted teeth at adult patient and our propose clinical approach.

Materials and methods: The clinical case is showed from adult man /64-year old/ with multiple impacted teeth $(6$ impacted teeth in the anterior place on the mandible) were not suggestive of any syndrome or metabolic disorder. The extraction of the impacted teeth was made on two stage with piezosurgery unit under local anaesthesia. For prevention of postsurgical complications, as a swelling and prevention of postsurgical resorbtion were used coneshapes from pressure xeno colagen. To base on clinical and radiological examination we will discuss the differential diagnosis and we will offer a clinical approach about decided the case.

Result and Conclusion: The incidence of multiple retained teeth by literature research range from $10.9 \%$ to $40.4 \%$, most frequently is the retention of the third molars. In the literature most rarely have clinical reports about multiple retained teeth which differ from third molars at adult patients. The rare clinical case we showed is very demonstrative and the medicative approach which we used gave excellent result.
\end{abstract}

Key words: mandible, multiple retention.

\section{INTRODUCTION:}

In world scientifical literature different autors give variety of definition in connection with retention. According to Velcheva (1) determinate retention is out of reach of occlusive level by completely rooth growth. Zausaev et al (2) mark as retention is stoppage in pierce as a result injure toothdental system. Magnusson, Kjellberg (14) devide retention on primary and secondary. The primary retention is the inerrupted cutting of a correctly developed and situated bud before it emerges in the oral cavity, secondary retention is the inhibition of eruption process after the tooth appears in the stoma. Other autors which divide the retention on primary and secondary are Dobbroczynska B, KreftaA, Szyszkowska M (6), Becktor KB (3) et al, Raghoebar GM(12) et al. Maaita (11) conducted epidemiological studies in 600 patients and the results are: $40.4 \%$ had four third molars impacted. Yildirim., Yilmas HH., Aydin U (20) described a clinical case on 55-year-old. In the total the patient had 28 impacted teeth - 13 impacted teeth in the maxilla and 15 impacted teeth in mandible. Miyazaki S et al (13). experienced a rare case of multiple impacted teeth in a 13 year 8month old boy. There was an impaction of the upper right canine, supernumerary teeth between the lower first and second premolars and at the distoposition of the upper right second premolar. Celicel DG., Erbay E., Gumru O (4) presented a case of patient with 6 impacted tooth in mandible. Srivatsan P., Babu NAv (17) in their article about multiple retenion showed case with 8 impacted teeth in mandible (one canine, two premolar - like supplemental teeth on each side and a distomolar in the right and left quadrants). Hirose $\mathrm{K}$ et al (8) showed a case of multiple impacted teeth in upper jaw associated which large follicular cyst in the right maxillary sinus. The teeth erupted spontaneously after reduction of the lesion. Kitai $\mathrm{N}$ et al (9) showed a case of 15-year-old patient with 11 impacted teeth including 2 supernumerary teeth, which did not exhibit hereditary or clinical disease.

\section{PURPOSE:}

The aim of this science report is to show a rare case of multiple impacted teeth at adult patient and our propose clinical approach.

\section{MATERIALS AND METHODS:}

The patient A. A. 64 - year-old proceeding the Department of Oral Surgery. We made a clinical and a radiological examination and we determinated multiple retention- retained and semiretained teeth in frontal section in lower jaw. (fig. 1,2). The anamnestic dates evidence a dull pain and a render difficult wearing of lower prostheses. From clinical examination was determinated a bloodshot gingiva in erupted teeth region. The team followed two stages surgical protocol with assistance piezosurgical unit. (fig 2, 3, 4, 7, 8). Under the local anesthesia arised mucoperiosteal flap by means of classical vestibular approach. By decrease postoperative oedema and prevention postremoval atrophy were used coneshapes from pressure xeno colagen. (fig. 5, 6). The flap was sutured. The recovery period were no further complaints or complications registered. 


\section{DISCUSSION:}

In the world literature discussion is connection with multiple retention close to third molars was done from many autors and rare by the other group's teeth. Most frequently multiple retention is connection with different syndroms. (4, $8,9,11,13,17,20)$. The surgical treatment on the retained teeth is related to cover the bone around them. The abolition of bone performing by means of hammer and chisel, surgical burs and last years with piezosurgical methods. According to Labanca $\mathrm{M}$ et al (10) the use of ultrasonic vibrations for the cutting of bone was first introduced two decades ago. It also reduces damage to osteocytes and permits good survival of bony cells. This method (19) find out appliance in the orthodontic microsurgery at horizontal and vertical coricotomies at transference the teeth in malposition and the treatment on malocclusion. The contemporary piezosurgical method utilizing in oral surgery about cutting the bone and multiple surgical intervention as a: lateral sinus lift, to shape the wholes for the implants, lateral transposition inferior alveolar nerve, $(5,16,18)$, caudal tranposition of the mental nerve in postoperative neurosensory controls by pain and hyperaesthesia caused by a dental prosthesis (15), takings a bone grafts and bone pieces and removal the teeth. $(5,16$, 18), By piezosurgery are using microvibrations on special ultrasonic scalers by what achieving highly precise and safe cutting of hard tissue; nerves, vessels, and soft tissue are not injured, the bone cuts in a selective and an atraumatic manner. (18). It was determinated that the intraosseous temperature develop of ultrasonic bone surgery devices appears not to be in the clinically critical range and differences in the cutting performance and intraosseous temperature development of the tested devices seemed to be influenced by the design of the cutting tips of the bone. (7).

\section{CONCLUSIONS:}

1. Is was done from us clinically and radiological analysis by means of orthopantomography is sufficiently for diagnosis on the multiple retention

2. The using of piezosurgical unit by extraction decrease percentage of postoperative complications.
Fig. 1.

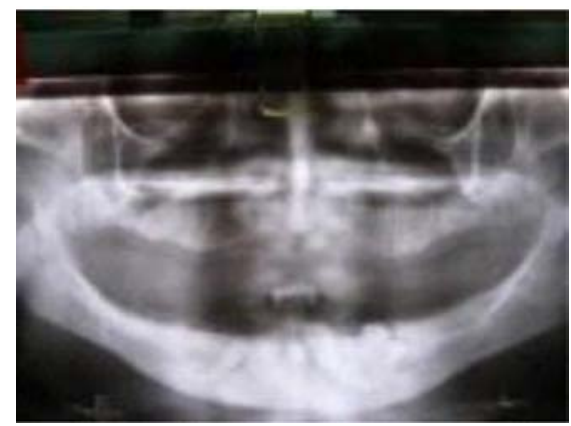

Fig. 3.

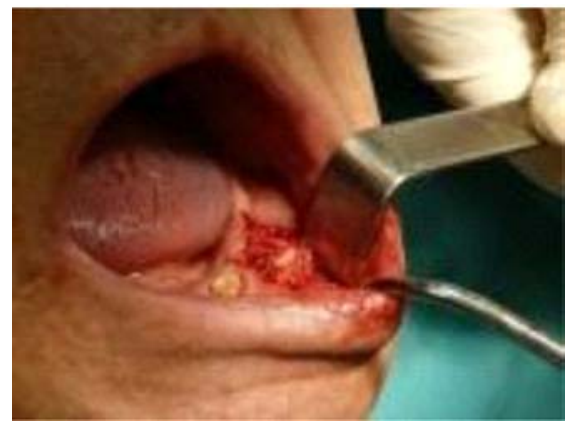

Fig. 5.

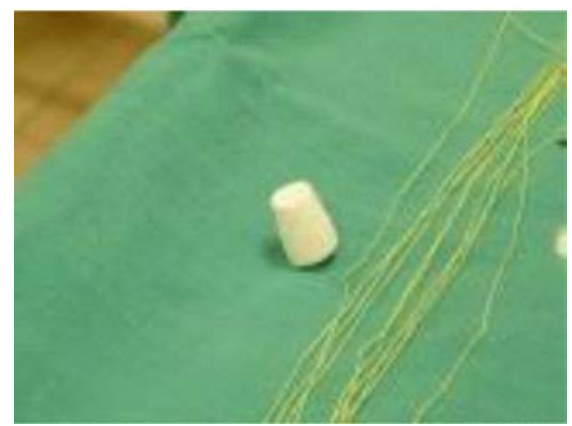

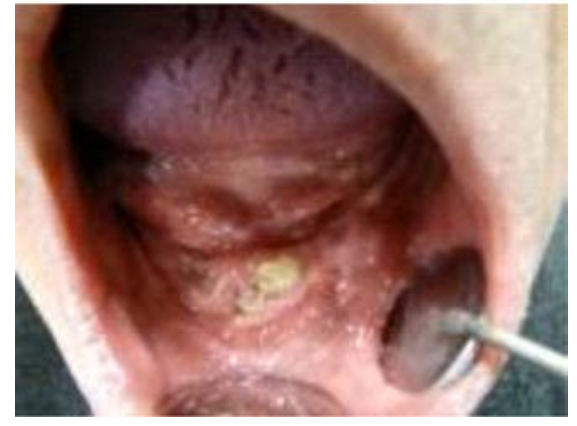

Fig. 2.

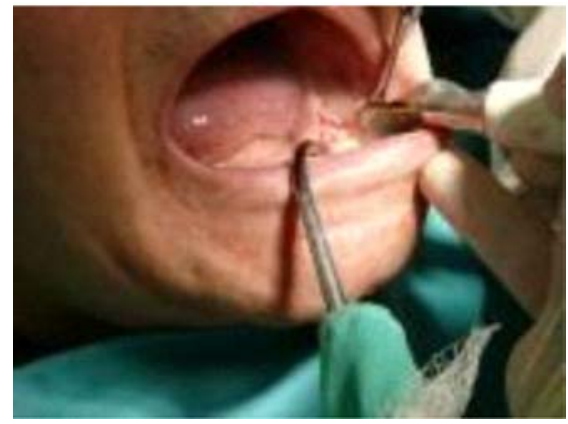

Fig. 4.

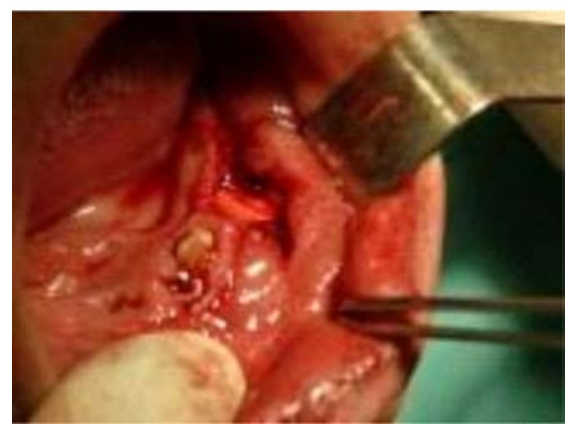

Fig. 6. 

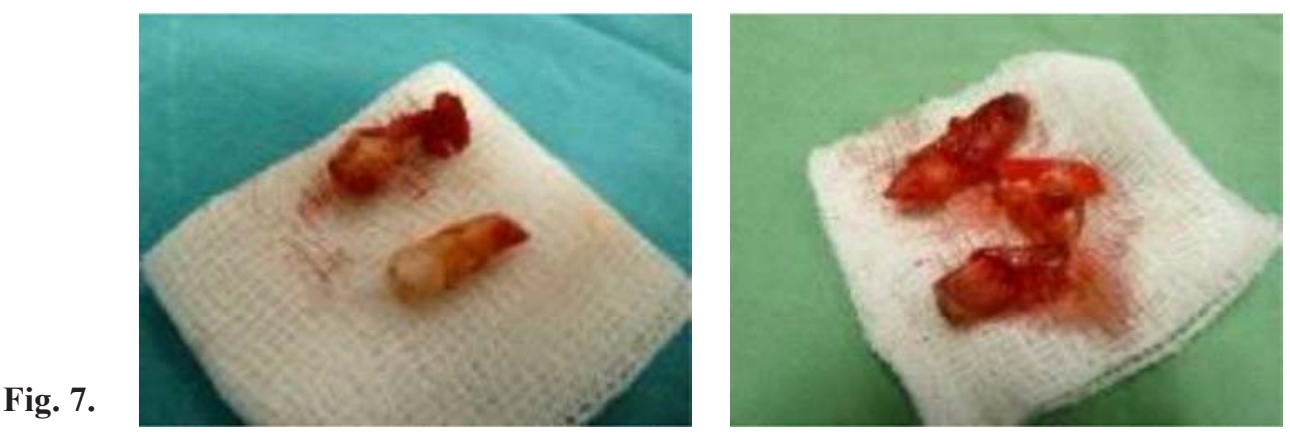

Fig. 8.

\section{REFERENCES:}

1. Велчева Л. Индикации за премахване на мъдреци. Съвременна стоматология. XXXIII. 2002; (3): 40

2. Заусаев ВИ, Наумов ПВ, Новоселов РД, Робустова ТГ, Карапетян ИС. Болести прорезьвания зубов (затрудненное прорезьвания зубов). Хирургическая стоматология 1981; VI: 133

3. Becktor KB., Bangstrup MI., Roling S., Kjaer I. Unilateral primary or secondary retention of permanent teeth, and dental malformations. European Journal of Orthodontics 24(2002): 205-214

4. Celikel DG., Erbay E., Gumru O. Treatment of Multiple Impacted Teeth in Mandible: A Case Report.

5. Degerliyuirt K, Akar V, Denizci S, Yucel E. Bone lid technique with piezosurgery to preserve inferior alveolar nerve. Oral Surgery, Oral Med, Oral Pathol, Oral Radiol Endod, 2009; 108(6): e1-e5 6. Dobbroczynska B, Krefta A, Szyszkowska M. 1. 1. Annales Universitta is Maria E Curie-Sklodowska Lublin Polonia 2006; 2 (180):996-997

7. Harder S., Wolfart S., Mehl C., Kern M. Performance of Ultrasonic Devices for Bone Surgery and Associated Intraosseos Temperature Development. The International Journal of Oral \& Maxillofacial Implants. 2009; 24(3): 489

8. Hirose K., Suzuki S., Kuroda T. A Long-term Follow- up Case of Multiple Impacted Teeth Assosiated with Large
Follicular Cyst in Maxilla. Journal of the Stomatological Society. 2000; 67(2): 213220

9. Kitai N., Fujii Y., Murakami S., Takada K. Three-dimensional evaluation of a rare case with a multiple impacted teeth using CT. Journal of Clinicl Pediatric Dentistry. 2003;28(2): 117-121

10. Labanca M., Azzola F., Vinci R., Rodella LF. Piezoelectric surgery: Twenty years of use. British Journal of Oral and Maxillofacial Surgery. 2008; 46(4): 265269

11. Ma aita JK. Impacted third molars and associated pathology in Jordanian patients. The Saudi Dental Journal 2000;12(1):16-1

12. Magnusson C., Kjellberg H. Impaction and Retention of Second Molars: Diagnosis, Treatment and Outcome . An International Journal of Orthodontics and Dentofacial Orthopedics 2009; 79(3):422427.

13. Miyazaki S., Kyboyama H., Toyomura S., Ryu C., Ishida M., Motokawa W. A Case of Multiple Impacted Teeth. Japanese Journal of Pediatric Dentistry. 2000;38(1): 242-248

14. Raghoebar GM., Boering G., Vissink A., Stegenga B. Eruption disturbances of permanent molars: a review. Journal of Oral Pathology\&Medicine.2006, 20(4): 159-66.

15. Sakkas N., Otten J-E., Gutwald R.,
Schmelzeisen R. Transposition of the mental nerve by piezosurgery followed by postoperative neurosensory control: A case report. British Journal of Oral and Maxillofacial Surgery. 2008; 46(4): 270271

16. Sortino F, Pedulla E, Masoli V. The piezoelectric and rotatory osteotomy tehnique in impacted third molar surgery: comparison of postoperative recovery. J Oral Maxillofac Surg. 2008;66(12): 244487

17. Srivatsan P., Babu NA. Mesiodens with an unusual morphology and multiple impacted supernumerary teeth in a nonsyndromic patient. Indian Journal of Dental Research. 2007; 18(3): 138-140

18. Stubinger S., Kuttenberger J., Filippi A., Sader R., Zeilhofer H-F. Intraoral Piezosurgery: Preliminary Results of a New Technique. Journal of Oral and Maxillofacial Surgery, 2005; 63(9): 12831287

19. Vercelloti T., Podesta A. Orthodontic microsurgery: A New Sugically Guided Technique for Dental Movement. The International Journal of Periodontics \& Restorative Dentistry. 2007; 27(4): 325

20. Yildirim D., Yilmas HH.,Aydin U. Multiple impacted permanent and deciduos teeth. Dentomaxillofacial Radiology. 2004;33:133-135

\section{Address for correspondence:}

Dr. Cvetan Cvetanov,

Department of Oral Surgery, Faculty of Stomatology, Medical University, Plovdiv 3,'Hristo Botev" bul., 4000 Plovdiv, Bulgaria

Tel.: +359/898325332

E-mail: doctorcvetanov@,abv.bg 